\title{
The Effects of Bancassurance: Reviews from The Perspectives of Banks, Insurers, and Customers
}

Nurul Farhana Nasir, Muhammad Nur Firdaus Nasir, Shazwani Mohd Salleh, Muhammad Arif Nasir, Amirah Hazimah Borhanordin, Muhammad Faiz Nasir

To Link this Article: http://dx.doi.org/10.6007/IJARBSS/v11-i5/10012 DOI:10.6007/IJARBSS/v11-i5/10012

Received: 23 March 2021, Revised: 25 April 2021, Accepted: 11 May 2021

Published Online: 24 May 2021

In-Text Citation: (Nasir et al., 2021)

To Cite this Article: Nasir, N. F., Nasir, M. N. F., Salleh, S. M., Nasir, M. A., Borhanordin, A. H., \& Nasir, M. F. (2021). The Effects of Bancassurance: Reviews from The Perspectives of Banks, Insurers, and Customers. International Journal of Academic Research in Business and Social Sciences, 11(5), 579-585.

Copyright: @ 2021 The Author(s)

Published by Human Resource Management Academic Research Society (www.hrmars.com)

This article is published under the Creative Commons Attribution (CC BY 4.0) license. Anyone may reproduce, distribute, translate and create derivative works of this article (for both commercial and non-commercial purposes), subject to full attribution to the original publication and authors. The full terms of this license may be seen at: http://creativecommons.org/licences/by/4.0/legalcode

Vol. 11, No. 5, 2021, Pg. 579 - 585

Full Terms \& Conditions of access and use can be found at http://hrmars.com/index.php/pages/detail/publication-ethics 


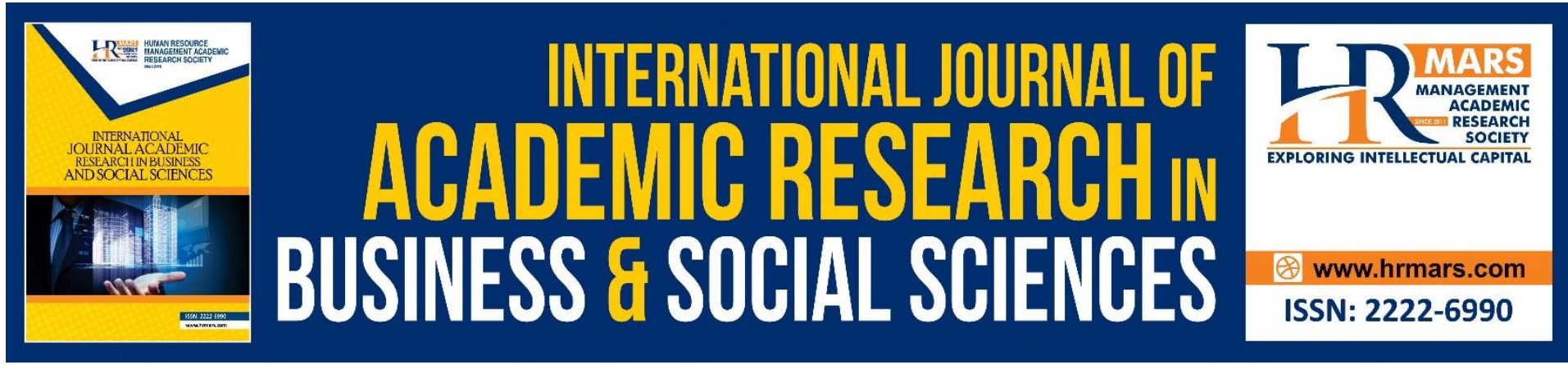

\title{
The Effects of Bancassurance: Reviews from The Perspectives of Banks, Insurers, and Customers
}

\author{
Nurul Farhana Nasir \\ Faculty of Business Management, Universiti Teknologi MARA, Shah Alam, Malaysia \\ Muhammad Nur Firdaus Nasir \\ Faculty of Art and Design, Universiti Teknologi MARA, Melaka, Malaysia \\ Shazwani Mohd Salleh \\ Faculty of Business Management, Universiti Teknologi MARA, Kedah, Malaysia

\section{Muhammad Arif Nasir} \\ Faculty of Hospitality Management and Tourism, Kolej Universiti Islam Melaka, Malaysia
}

\section{Amirah Hazimah Borhanordin}

Faculty of Business Management, Universiti Teknologi MARA, Melaka, Malaysia

\section{Muhammad Faiz Nasir}

Faculty of Business Management, Universiti Teknologi MARA, Shah Alam, Malaysia

\begin{abstract}
This conceptual paper examines bancassurance from the perspectives of banks, insurers, and customers. In general, bancassurance refers to the collaboration between banks and insurers to distribute insurance products to bank customers. In Malaysia, bancassurance significantly contributes to the growth of the Malaysia market. As the nature of the banking atmosphere grows more competitive, the role of bancassurance develops more meaningfully in this industry. In the context of this concern, this study seeks to discuss the concept of bancassurance and its benefits to the banking sector, insurance industry, and customers. This study would be useful to insurance companies and banking institutions to formulate strategies for sustainability of bancassurance in the industry.
\end{abstract}

Keywords: Bancassurance, Banking Sector, Insurance Industry, Malaysia.

\section{Introduction}

The insurance industry sector is considered as one of the growing sectors in Malaysia. The insurance industry today has emerged as important because it contributes to the growth and development of the economy since it is one of the overall components in the Malaysian 
financial system. Nevertheless, the insurance sector has been an important source to the economic development of Malaysia. Basically, there are a lot of contributions and efforts from the government and insurance practitioners around the world in order for the insurance system will become a strong financial system in the world.

Even though the insurance industry has grown rapidly in Malaysia, the penetration rate of general insurance should be taken into consideration. According to the industry report, as of 2019, the general insurance gap penetration only contributes 1.23 percent of the country gross domestic product (GDP). Obviously, this major indicator showed that penetration rate for general insurance in Malaysia remains low and there is still a large untapped market. Essentially, Malaysia is far behind as compared to other nations like Korea and Taiwan where the contributions is much higher, in the double digits.

Extending to the above paragraph, distribution channels are one of the ways to boost market share and insurance penetration for general insurance. In order to improve insurance growth and market penetration of insurance business a new concept called 'bancassurance' was introduced to strengthen this industry. According to Reportstack and Finaccord in their report "Bancassurance in the Asia-Pacific Region: Strategies of the Region's Top 150 Retail Banking Groups", as of 2015, some Asian countries such as Indonesia, Korea, India, Singapore, and the Philippines have shown the fastest growth market. Unfortunately, this is contradicting with Malaysia. Even though the existence of bancassurance in Malaysia has been more than two decades, there are still untapped markets compared to other Asian countries.

One of the challengers faced by the banks and insurance companies after implementing bancassurance is lack of awareness among the customers (Bansal \& Anil, 2018). Creating awareness among the customers is a crucial challenge faced by the industry. Although there are many insurance products in the market, there are still limited people to purchase this kind of products. Therefore, this conceptual paper explores the concept of bancassurance and the benefits of bancassurance to the banks, insurers (i.e. insurance companies), and customers.

\section{Concept of Bancassurance}

Bancassurance refers to an agreement between a bank and an insurance company. In bancassurance, the insurance company can use the bank's distribution channels to sell their products. In return, banks would receive certain fee from the insurance company. According to Agbo and Nwankwo (2020), the term bancassurance is derived by compounding 'bank' and 'insurance'. Meanwhile, a study by Yuan (2011) indicated bancassurance as a process of a bank selling insurance products manufactured by insurance subsidiaries that are owned by the bank, either through its own distribution channels or through outside agents. By conducting a scan of materials on published studies on bancassurance, this study has found researches from many countries.

Table 1: International academic research studies on bancassurance

\begin{tabular}{|l|l|}
\hline \multicolumn{1}{|c|}{ Country } & \multicolumn{1}{c|}{ Research Study } \\
\hline Algeria & Hamoul, Zair, \& Mokhefi, 2018 \\
\hline Bulgaria & Ninova, 2018 \\
\hline
\end{tabular}




\begin{tabular}{|l|l|}
\hline China & Huo, 2016 \\
\hline Hungary & Pintér, 2013 \\
\hline India & Deepa \& Rafi, 2020; Devi, 2020; Devi, 2019; Dua, Sahay, \& Deol, \\
& $\begin{array}{l}\text { 2019; Kale, 2019; Gujral, 2018a; Gujral 2018b; Kumar, 2017; Brar \& } \\
\text { Singh, 2016; Choudhury \& Singh, 2016; Choudhury, Singh, \& Saikia, } \\
\text { 2016; Ranganath \& Rao, 2016; Bhushan \& Murtaza, 2014; Ali \& } \\
\\
\text { Chatley, 2013; Mishra, 2012 }\end{array}$ \\
\hline Indonesia & Zahara, 2020 \\
\hline Iraq & Al-Ubaidy, 2020 \\
\hline Ireland & Brophy, 2013 \\
\hline Kenya & Dolvine \& Muturi, 2019 \\
\hline Latvia & Dundure \& Sloka, 2019 \\
\hline Malaysia & Boon, Chein, \& Yittjia, 2012 \\
\hline Nigeria & Agbo \& Nwankwo, 2020; Nwora, 2018 \\
\hline Spain & Guillem, 2020 \\
\hline Taiwan & Pang-Ru, Jin-Lung \& Chiang, 2011 \\
\hline Turkey & Tunay, 2014 \\
\hline
\end{tabular}

Bancassurance in Malaysia has witnessed a tremendous growth in terms of demand, acceptance and development since the first arrangement was approved by Bank Negara Malaysia (Central Bank of Malaysia) in late 1993. Bancassurance is actively supported in Malaysia because it is seen to lead to a more efficient financial system. In Malaysia, bancassurance is considered as a second distribution channel behind agents and the products are broadly categorized into credit-related and noncredit related products. Bank staffs who sell insurance products are required to satisfy the same minimum qualification and continuous professional development requirement as insurance agents, and comply to the same code of ethics.

\section{Benefits of Bancassurance to Banks, Insurers (i.e. insurance companies), and Customers}

Basically, bancassurance gives benefits to banks, insurers, and customers. Bancassurance allow banks to cater to customers' specific needs, provide greater accessibility, when and where needed. Secondly, bancassurance is viewed as the distribution channels by the banks as it reaches out to different target groups. Thirdly, bancassurance gives benefits to banks by strengthening their position in providing end-to-end financing solutions for both individuals and small and medium enterprise (SME) community.

Hence, this would help banks to strengthen their capability to provide a comprehensive solutions for customers - businesses and individuals alike. Next, bancassurance offers greater income stability and a more stable source of fee-based income for banks. In addition, bancassurance would allow the bank to optimize customer information and infrastructure to provide insurance-based products to its clients.

From the point of view of insurers (i.e. insurance companies), bancassurance is one of the strategies to boost the insurance industry, as the current contribution from the insurance premiums to the country's Gross Domestic Product (GDP) is still low. Secondly, by partnering with banking institutions, insurers can tap the banks' large customer base as potential clients for insurance products. Thirdly, by pursuing new distribution strategies (i.e. bancassurance), 
insurers will strengthen their expertise and resources, in order to manage and control the risks associated with that channel.

Meanwhile, bancassurance gives benefits to customers by allowing customers to compare products offered by different companies as easily accessible information is provided by the banks. This is because bancassurance products are basically more affordable due to the pricing structure. Secondly, bancassurance cater to customers' financial needs under one roof, especially customers who are from the lower- to middle-income earners who favor affordable products with the same level of coverage as those offered by the agents. Thirdly, customers trust their banks to sell them the right products. Hence, the propensity of the customers to buy insurance products from their banks is higher because they already know the reputation of the banks.

\section{Conclusion and Recommendations}

Generally, bancassurance is definitely a growing and leading distribution channel in Malaysia. Insurance companies are using banks as intermediaries to sell their products due to the wider network of the banks. Banks are taking this opportunity to grow their income in order to maintain their sustainability in the long run. Essentially, the strong business relationship with the bank partners and the ability to understand and work based on the banks' specific needs also contributed to the growth of bancassurance. Bancassurance is a distribution channel to ensure that insurance needs are adequate by providing accessibility and affordability.

Bancassurance has a bright future in Malaysia. It is recommended that banks and insurance companies look forward to implementing strategies to put bancassurance as one of the incredible products distributed in the industry. Firstly, it is recommended that banks provide appropriate training to their employees in order to build their employees' confidence when responding to customers queries in regards to bancassurance.

Secondly, it is important that insurance companies and banks implement product diversification strategy to increase their sales. Customers nowadays are more intellectual and they are interested to know what they will get in the future. Therefore, fulfilling customers' needs and wants by diversifying the products is one of the best strategies to leverage existing sales avenues. Thirdly, banks should ensure that they settle any claims promptly to make sure their customers trust them. Building a good reputation is important to ensure sustainability of the banks in this competitive industry.

Last but not least, this study contributes to a theoretical and practical standpoints. From a theoretical standpoint, this study explores the concept of bancassurance and therefore provides valuable information on the contextual applications. From a practical perspective, this study contributes valuable inputs to those in the industry for the development and implementation of strategies for bancassurance. As a key contributor to the economy, the performance of the insurance industry will indeed be crucial in ensuring the economic growth of the nation.

\section{References}

Agbo, E. I., \& Nwankwo, S. N. (2020). Bancassurance in Africe: Avenue for insurance inclusion. Business Management and Entrepreneurship Academic Journal, 2(9), 44-56. 
Ali, L., \& Chatley, P. (2013). Customer perception of bancassurance: A Survey. European Journal of Business and Management, 5(22), 34-46.

Al-Ubaidy, S. B. (2020). The reality of Bancassurance in Iraqi banks (Applied research in a sample of Iraqi banks). Journal of Hematology.

Bansal, J., \& Anil, K. (2018). Qualitative Research on Issues and Trends in the Bancassurance Model in India: An Interview Report. International Journal of Banking, Risk and Insurance, 6(2), 67-78.

Bhushan, P., \& Murtaza, M. A. (2014). Bancassurance: The Indian Scenario. In 2014 NIT-MTMI International Conference on Emerging Paradigms and Practices in Global Technology, Management \& Business Issues December 22-24, 2014.

Boon, L. K., Chein, T. S., \& Yittjia, C. (2012). User acceptance of bancassurance in Malaysia. In Proceeding International Conference on Management, Economics, and Finance (ICMEF).

Brar, A. S., \& Singh, S. (2016). Bancassurance: A Study in relation to Total Income \& Branch Network of Private Sector Banks in India. IOSR Journal of Business and Management (IOSR-JBM), Special Issue - AETM'16, 43-47.

Brophy, R. (2013). Bancassurance: an insurance concept from a Irish perspective. Journal of Financial Regulation and Compliance, 21(4), 319-333.

Choudhury, M., \& Singh, R. (2016). Customers' Perception regarding Assurance of Bancassurance Channel. Acta Univ. Sapientiae, Economics and Business, 4, 85-102.

Choudhury, M., Singh, R., \& Saikia, H. (2016). Measuring customer experience in bancassurance: An empirical study. Market-tržište, 28(1), 47-62.

Deepa \& Rafi, H. (2020). A Study of consumer behavior towards bancassurance and their issues affecting branch activation. International Journal of Advanced Science and Technology, 29(3s), 1655-1664.

Devi, P. P. (2019). Bancassurance: A Marketing perspective. International Journal of Civil Engineering and Technology (IJCIET), 10(3), 2093-2102.

Devi, P. P. (2020). Bancassurance and its antecedents to customer buying intentions. In AIP Conference Proceedings.

Dolvine, O. N., \& Muturi, W. (2019). Influence of bancassurance on financial performance of commercial banks in Kenya. International Journal of Social Sciences and Information Technology, V(V), 63-74.

Dua, P., Sahay, N., \& Deol, O. S. (2019). Bancassurance model and its impact on Financial Inclusion: Review and Analysis. International Journal of Research and Analytical Reviews (IJRAR), 6(2), 661-669.

Dundure, E., \& Sloka, B. (2019). Market environment factors influence on development of bancassurance in Latvia. Regional Formation and Development Studies, 2(28), 54-64.

Gujral, T. M. (2018a). Recent Emergent Scenario of Bancassurance in India.

Gujral, T. M. (2018b). Contemporary Prominent Development of Bancassurance in India. Research Review International Journal of Multidisciplinary, 3(10), 731738.

Guillem, M. A. L. (2020). The Customer Orientation Service of Spanish Brokers in the Insurance Industry: The Advisory Service of the Insurance Distribution Channel Bancassurance. Sustainability, 12, 1-22. 
Hamoul, T., Zair, W., \& Mokhefi, A. (2018). The consolidation strategy between banks and insurance company- Case of Algeria. International Journal of Research Science \& Management, 5(1), 8-15.

Huo, Y. (2017). Risk Management Analysis on Bancassurance Model in Bank of Communications Changchun Branch. Advances in Social Science, Education and Humanities Research, 85, 1002-1004.

Kale, P. G. (2019). Measuring Channel Partners Experience in Bancassurance: An Empirical Study. International Journal of Trend in Scientific Research and Development (IJTSRD), 3(4), 552-555.

Kumar, R. (2017). Bancassurance: Emerging prospects and issues in India. International Journal of Academic Research and Development, 2(1), 33-36.

Mishra, N. (2012). Bancassurance: Problems and challenges in India. Integral Review- A Journal of Management, 5(1), 52-63.

Ninova, V. (2018). Bancassurance - Application and Advantages for the Insurance Market in Bulgaria. Journal of Innovations and Sustainability, 4(2), 9-21.

Nwora, N. G. (2018). The Revised Guidelines on Bancassurance Operation in Nigeria: Marketing Implications on Patronage of Insurance Products. Journal of Public Management Research, 4(2), 29-46.

Pang-Ru, C., Jin-Lung, P., \& Chiang, K. F. (2011). A Comparison of Bancassurance and Traditional Insurer Sales Channels. The Geneva Papers on Risk and Insurance - Issues and Practice, Palgrave Macmillan; The Geneva Association, 36(1), 76-93.

Pintér, É. (2013). Strategic and Marketing Aspect of Bancassurance - Service Innovation in Hungary. IPEDR, V59(26), 126-130.

Ranganath, N. S., \& Rao, G. T. (2016). The Impact of Bancassurance on Efficiency of Banking Sector in India - An Empirical Study. International Journal of Innovative Research and Practices, 4(2), 1-13.

Tunay, N. (2014). Bancassurance Applications in Turkey and its Dynamic Effects of Turkish Banking and Insurance Sectors. Journal of BRSA Banking and Financial Markets, 8(1), 35-62.

Yuan, Y. (2011). U.S. financial services integration: An evidence in banking and insurance. Academy of Banking Studies Journal, 10(1), 53-110

Zahara, N. (2020). Sistem Pertanggungan Pada Penjaminan Bancassurance oleh Asuransi X Syariah Menurut Konsep Kafālah. Tawazun: Journal of Sharia Economic Law, 3(1), 1-14. 